\title{
DNA index and $S$ phase fraction in uveal malignant melanomas
}

William G Hodge, Alain J Duclos, Guillermo Rocha, Emilia Antecka, Malcolm G Baines, Christine Corriveau, Seymour Brownstein, Jean Deschenes

\begin{abstract}
Aims-To predict 5 year survival in patients with uveal malignant melanomas DNA indices were studied.

Methods-Using 45 paraffin embedded uveal malignant melanomas, the DNA index and $S$ phase fraction of each tumour were the predictor variables recorded.

Results-Using the Cox proportional hazards model, aneuploid tumours and tumours which had an $S$ phase fraction greater than $4 \%$ were significant predictors of early death. In order to demonstrate a biological gradient between a larger DNA index and shorter survival time, linear regression and transformed linear regression models were used. However, no such gradient could be demonstrated.

Conclusion-Although this study shows promise for the use of DNA studies in the prognosis of uveal malignant melanoma, the exact role of these techniques remains to be determined.
\end{abstract}

(Brf Ophthalmol 1995; 79: 521-526)
Several variables are felt to be important with respect to prognosis in ocular melanomas involving the uveal tract. Some of these variables include the tumour size, its most anterior intraocular extension, extraocular extension, histopathological cell type, variance in nucleolar area, mitotic index, ${ }^{1}$ and vascular patterns within the tumour. ${ }^{2}$ Many of these are indirect measurements of the DNA content and activity of the tumour cells. With flow cytometry, DNA studies can be performed directly and efficiently.

The flow cytometer ${ }^{3}$ is a device that can tabulate the DNA content and proliferative activity of cells at a rate well over 1000 cells per second. Through a differential pressure mechanism, the sample flows through a tube of predetermined diameter allowing cells already stained with a DNA specific fluorescent dye to be illuminated by an argon light source one cell at a time. This is called hydrostatic focusing. A complex optical system consisting of pinholes in series, dichroic mirrors, and filters then separate the emitted fluorescent light from the scattered reflected light. The light is then
McGill University, Montreal, Quebec, Canada

Department of Ophthalmology

W G Hodge

G Rocha

C Corriveau

$S$ Brownstein

J Deschenes

Department of Immunology

A J Duclos

E Antecka

M G Baines

Correspondence to:

Dr J Deschenes, 687 Pine Avenue West, Montreal, Quebec, Canada H3A 1A1.

Accepted for publication 10 January 1995

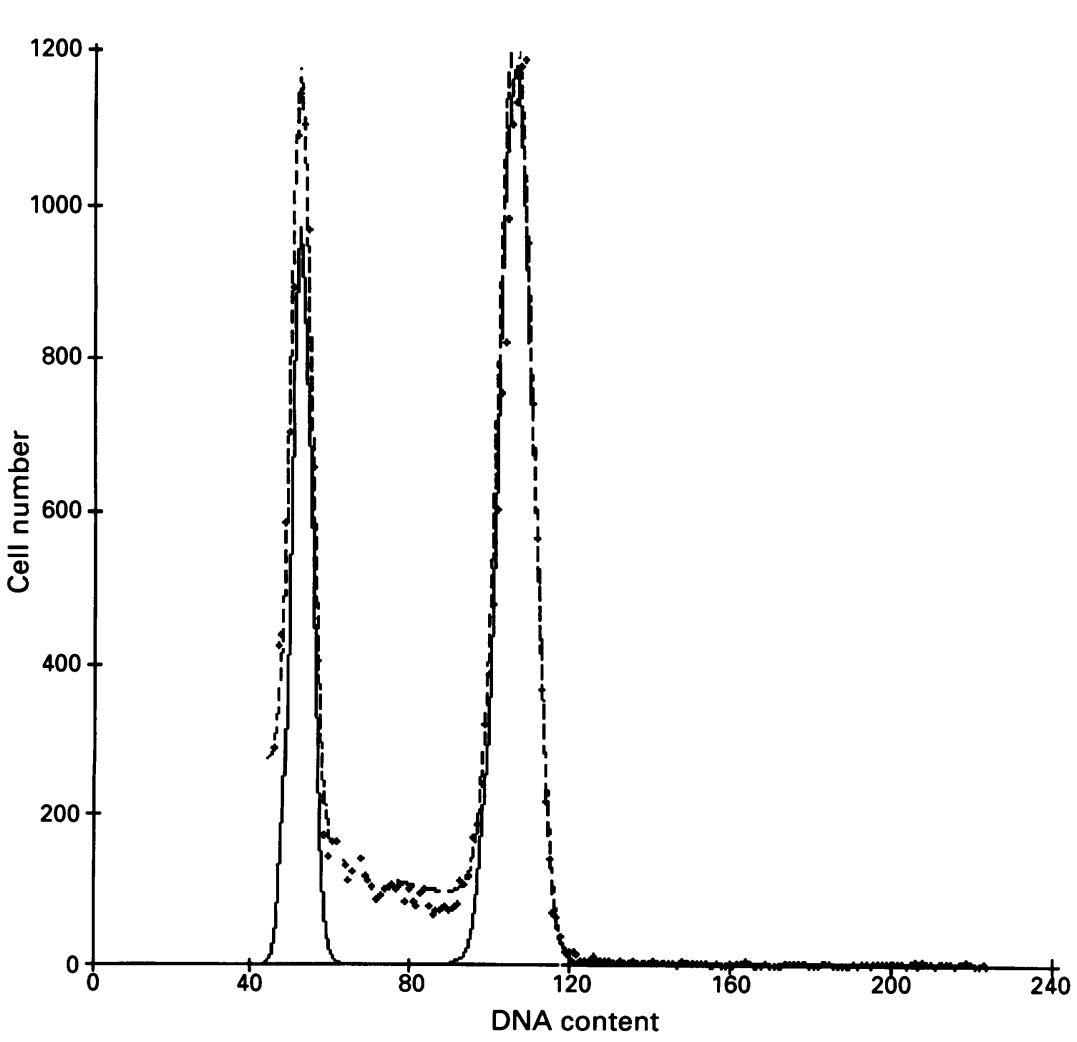

ANEUPLOID
CYCLE

Mean $\mathrm{G} 1=106 \cdot 6$

$\mathrm{CV} \mathrm{G1}=4.0$

$\%$ G1 $=99.1$

Mean G2 $=214 \cdot 3$

$\mathrm{CV} \mathrm{G2}=4.0$

$\%$ G2 $=0.2$

G2/G1 $=2.011$

$\%$ TOT $=67.0$

DI $\quad=2.014$

Figure 1 Flow cytometry histogram depicting a tumour with a DNA index of 100/50 or 2/1. 
transformed to electrical energy by a series of photomultiplier tubes. This energy is then quantified by an analogue to digital converter. A computer program then stores the data and presents them in graph form.

DNA studies have already been performed on several tumours with the aid of the flow cytometer. These include many haematological malignancies, ${ }^{4}$ oat cell carcinoma of the lung, ${ }^{5}$ carcinoma of the breast, ${ }^{6}$ adenocarcinoma of the large intestine, ${ }^{7}$ and malignant melanoma both of the skin $^{8}$ and uveal tract. ${ }^{9-11}$ In the present study, DNA indices of uveal malignant melanomas are correlated with histopathologic cell type and 5 year survival.

\section{Material and methods}

INCLUSION CRITERIA, EXCLUSION CRITERIA, AND CLINICAL VARIABLES

Consecutive sampling was used to obtain all paraffin embedded eyes enucleated for malignant melanoma of the uveal tract from the ocular pathology archives of McGill University between 1968 and 1986. All iris melanomas were excluded from the study. The principal clinical outcome variable measured was 5 year survival or time to death. Potential confounders measured included age at diagnosis, sex, race, and other past or present ocular or systemic diseases. Any patient who did not have follow up complete to 5 years was excluded from the study. Also excluded were any patients with any other malignancy.

\section{TISSUE PROCESSING AND FLOW CYTOMETRIC} VARIABLES MEASURED

The precise detail of tissue processing for flow cytometry has been described elsewhere. ${ }^{12}$ Briefly, $50 \mu \mathrm{m}$ slices of tissue were obtained from each block using a microtome. Paraffin was removed with three 10 minute changes of xylene and the tissue slices rehydrated through ethanol to water. The cell proteins were digested with pepsin $(0.5 \mathrm{~g}$ in $4.0 \mathrm{ml}, \mathrm{pH} 1.5)$ and the RNA digested with RNAse (350 units in $5 \mathrm{ml}$ aliquot). The DNA in the isolated nuclei was then stained with propidium iodide ( $5 \mathrm{mg} / 100 \mathrm{ml}, \mathrm{pH} \mathrm{7 \cdot 4}$ ). The DNA index (DI) and $S$ phase fraction (SPF) of each tumour were the predictor variables recorded.

The guidelines used for interpretation of SPF and DI were those proposed by the Convention on Nomenclature for DNA Cytometry in 1984 and refined by the Society of Analytical Cytology Subcommittee, SAC XIV March 1990; the most pertinent of which for this study can be summarised as follows.

Figure 1 illustrates the concept of aneuploidy. Aneuploidy ${ }^{13}$ simply indicates an abnormal amount of cellular DNA, usually accompanied by an abnormal chromosome number. The flow cytometer always reveals a diploid peak (G0/G1) corresponding to a cell population with a normal number of chromosomes. If an aneuploid population exists, a second peak will also be expressed after the first one as in Figure 1. To be considered significant, this aneuploid peak must be at least $10 \%$ of the height of the diploid peak. Moreover, the peak width at half maximum height divided by 2.35 must be less than $8 \%$ the coefficient of variation (CV). To calculate the DI, one simply divides the aneuploid peak by the diploid peak along the $x$ axis. Therefore, in the tumour shown in Figure 1, the DI would be approximately 100 fluorescence units divided by 50 fluorescence units or $2 / 1$. Scales are arbitrary fluorescence units, but form a linear representation of fluorescence intensity and are therefore considered to be proportional to the amount of dye in the nucleus and thus DNA content. We used normal optic nerve tissue as a diploid control (Fig 2). It has, of course, only a single diploid peak centred at approximately 50 fluorescence units. All diploid peaks from our tumour were verified against an optic nerve tissue control.

The SPF is a measure of the percentage of cells in the DNA synthesis phase of the cell cycle. ${ }^{14} \mathrm{~S}$ phase cells form a subpopulation with a level of DNA related fluorescence intermediate between the G0/G1 peak and the G2/M peak. It is therefore a calculated value based on these peak areas. The $S$ phase fraction reported was calculated using the MULTICYCLE software package. The method used to fit the Gaussian peaks and the broadened second order polynomial is a non-linear least squares curve fitting. The value is displayed to the right of the histogram in Figure 3.

HISTOPATHOLOGY

The histopathological type was the outcome variable recorded from ocular pathology records that had been read by an ocular pathologist (SB). Both haematoxylin and eosin and potassium permanganate bleached specimens were studied for each tumour.

\section{STATISTICAL ANALYSIS}

The two principal predictor variables in this study were the DI and SPF. The two main outcome variables measured were survival and histopathological type. To determine whether either the DI or SPF correlated with survival, the multivariate Cox proportional hazards model was used controlling for confounders previously mentioned. Furthermore, univariate Kaplan-Meier curves were constructed and the log rank test was used to estimate the difference in survival. When calculating whether either predictor variable correlated with pathological type, the data were modelled by stepwise multiple logistic regression, again controlling for the confounders previously mentioned.

\section{Results}

\section{DESCRIPTIVE DATA}

Forty five paraffin embedded tumours were used in the study. Pathological analysis was performed on all specimens. Twenty five of the 
Cell cycle data

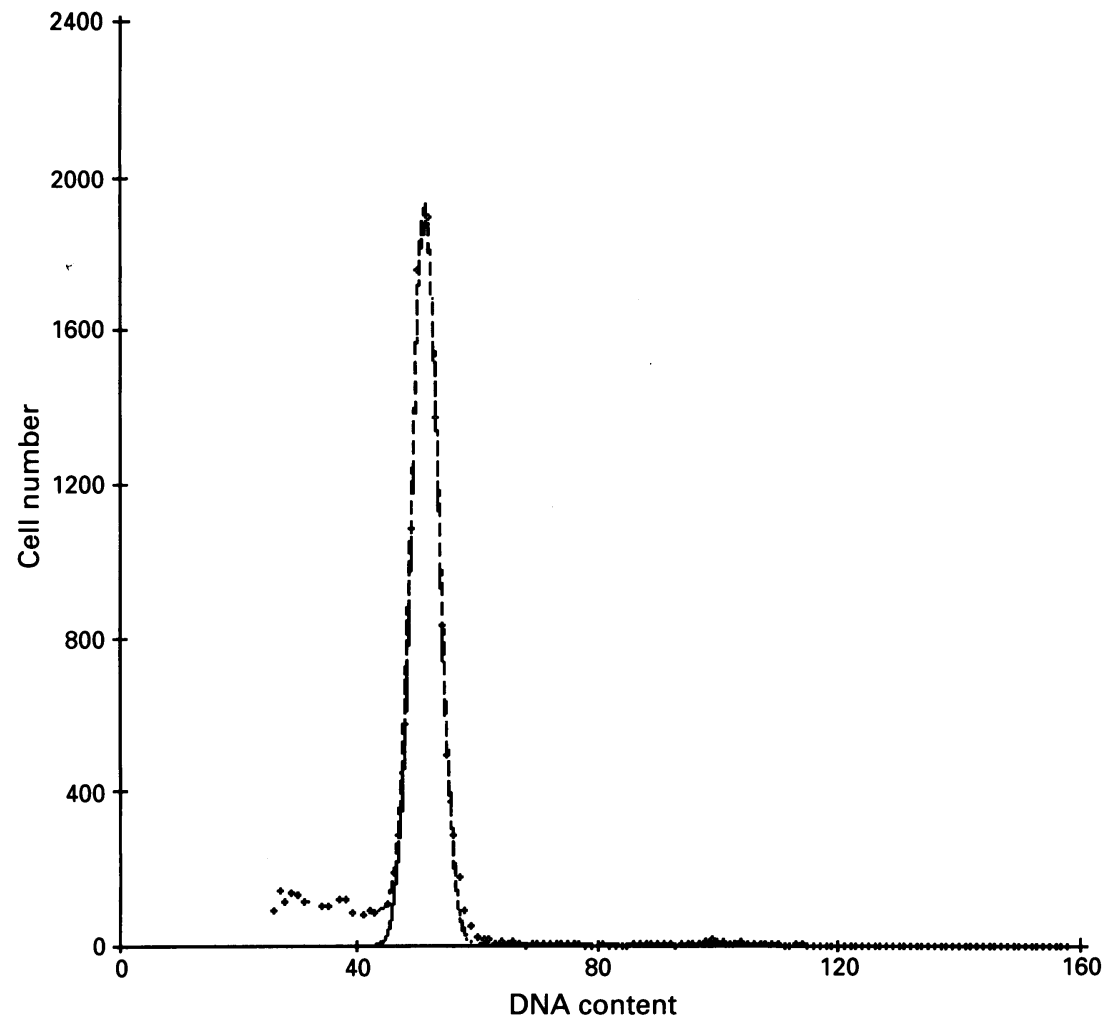

DIPLOID CYCLE

Mean $\mathrm{G} 1=51.4$

$\mathrm{CV} \mathrm{G1}=4.3$

Mean $\mathrm{G} 2=101 \cdot 2$

$\mathrm{CV}$ G2 $=3.9$

$\% \mathrm{G} 2=1.7$

$\% \mathrm{~S} \quad=1.0$

$\mathrm{G} 2 / \mathrm{G} 1=1.969$

Figure 2 Flow cytometry histogram of a normal optic nerve used as a control.

tumours were of the spindle B type, the remaining were mixed cell tumours. Twenty seven of the 45 patients were male $(60 \%)$. Forty patients $(89 \%)$ were white, the remainder were black. The mean age at the time of enucleation was 60.6 (range 39-78) years. Eighteen of the 45 patients $(40 \%)$ died within 5 years of follow up. The mean age at the time of death was 65.0 (range 42-79) years. These descriptive data can be found in Table 1.

DNA INDEX AND SURVIVAL

Using the multivariate Cox proportional hazard model, the relative risk of death in a patient with an aneuploid tumour compared

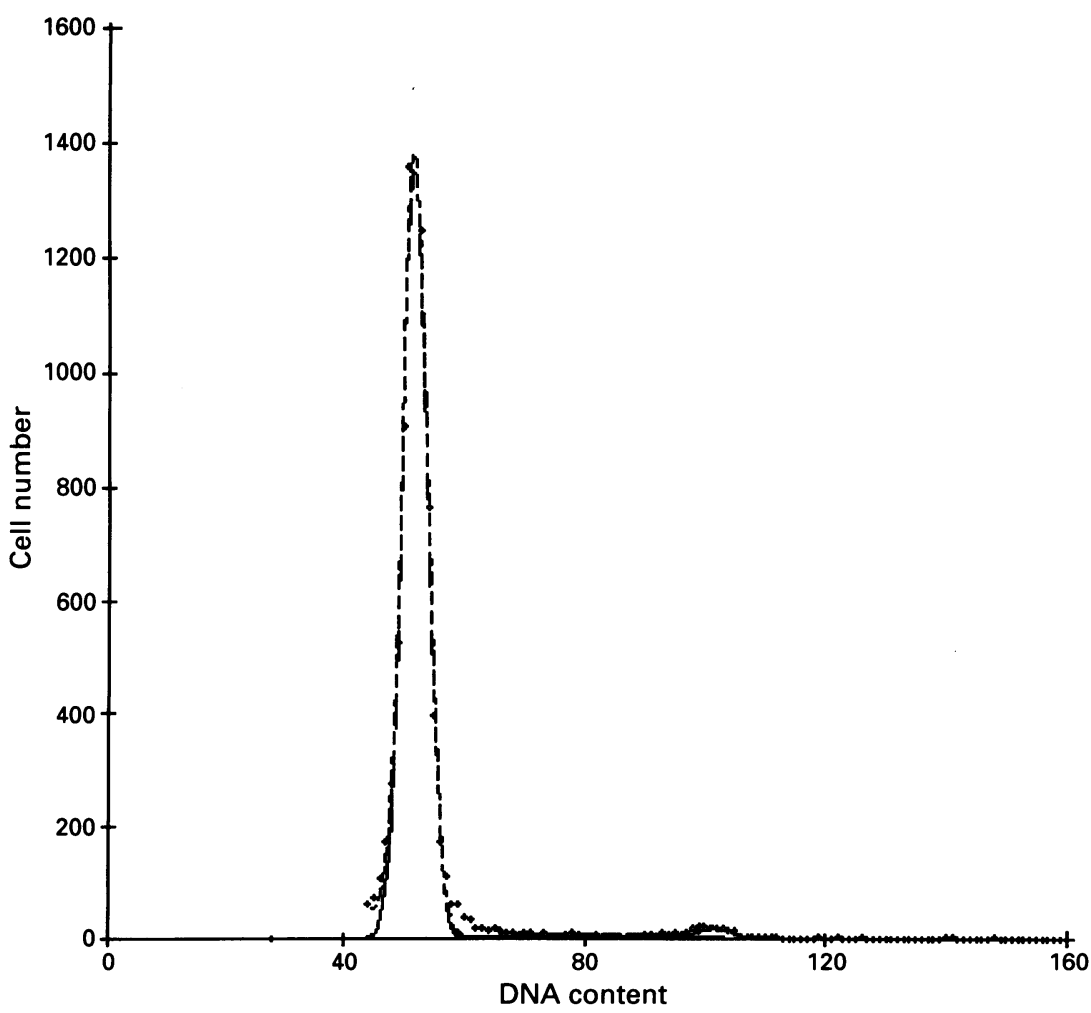

Cell cycle data

DIPLOID CYCLE

Mean $\mathrm{G} 1=51.8$

$\mathrm{CV} \mathrm{G1}=4.0$

$\% \mathrm{G} 1=94.9$

Mean $\mathrm{G} 2=101.6$

$\mathrm{CV} \mathrm{G2}=2.9$

$\%$ G2 $=1.7$

$\% \mathrm{~S} \quad=3.4$

$\mathrm{G} 2 / \mathrm{G} 1=1.960$

Figure 3 Flow cytometry histogram illustrating a tumour with an $S$ phase fraction of $3.4 \%$. 
Table 1 Descriptive data $(n=45)$

\begin{tabular}{|c|c|c|c|c|c|}
\hline Patient & Sex & Race & Pathology & $\begin{array}{l}5 \text { Year } \\
\text { status }\end{array}$ & $\begin{array}{l}\text { Age at } \\
\text { enucleation }\end{array}$ \\
\hline $\begin{array}{l}1 \\
2 \\
3 \\
4 \\
5 \\
6 \\
7 \\
8 \\
9 \\
10 \\
11 \\
12 \\
13 \\
14 \\
15 \\
16 \\
17 \\
18 \\
19 \\
20 \\
21 \\
22 \\
23 \\
24 \\
25 \\
26 \\
27 \\
28 \\
29 \\
30 \\
31 \\
32 \\
33 \\
34 \\
35 \\
36 \\
37 \\
38 \\
39 \\
40 \\
41 \\
42 \\
43 \\
44 \\
45\end{array}$ & 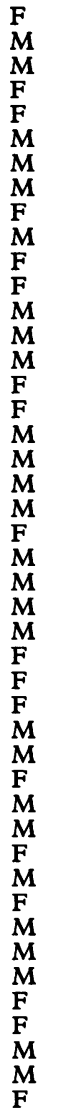 & 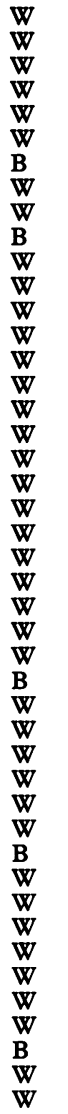 & $\begin{array}{l}\text { SP B } \\
\text { Mixed } \\
\text { SP B } \\
\text { Mixed } \\
\text { SP B } \\
\text { Mixed } \\
\text { SP B } \\
\text { SP B } \\
\text { Mixed } \\
\text { SP B } \\
\text { Mixed } \\
\text { Mixed } \\
\text { Mixed } \\
\text { SP B } \\
\text { Mixed } \\
\text { Mixed } \\
\text { Mixed } \\
\text { SP B } \\
\text { SP B } \\
\text { SP B } \\
\text { SP B } \\
\text { Mixed } \\
\text { SP B } \\
\text { SP B } \\
\text { Mixed } \\
\text { Mixed } \\
\text { Mixed } \\
\text { Mixed } \\
\text { SP B } \\
\text { Mixed } \\
\text { Mixed } \\
\text { SP B } \\
\text { SP B } \\
\text { SP B } \\
\text { SP B } \\
\text { SP B } \\
\text { SP B } \\
\text { SP B } \\
\text { Mixed } \\
\text { Mixed } \\
\text { Mixed } \\
\text { SP B } \\
\text { SP B } \\
\text { SP B } \\
\text { SP B }\end{array}$ & $\begin{array}{l}\text { A } \\
\text { A } \\
\text { A } \\
\text { A } \\
\text { A } \\
\text { A } \\
\text { A } \\
\text { A } \\
\text { D } \\
\text { A } \\
\text { A } \\
\text { A } \\
\text { A } \\
\text { A } \\
\text { D } \\
\text { A } \\
\text { D } \\
\text { A } \\
\text { A } \\
\text { D } \\
\text { D } \\
\text { D } \\
\text { D } \\
\text { A } \\
\text { D } \\
\text { D } \\
\text { D } \\
\text { D } \\
\text { A } \\
\text { D } \\
\text { A } \\
\text { D } \\
\text { A } \\
\text { A } \\
\text { D } \\
\text { A } \\
\text { A } \\
\text { A } \\
\text { D } \\
\text { A } \\
\text { D } \\
\text { A } \\
\text { D } \\
\text { D } \\
\text { A }\end{array}$ & $\begin{array}{l}61 \cdot 2 \\
43 \cdot 5 \\
61 \cdot 7 \\
59 \cdot 7 \\
64 \cdot 6 \\
71 \cdot 3 \\
78 \cdot 3 \\
50 \cdot 9 \\
68 \cdot 2 \\
44 \cdot 9 \\
53 \cdot 6 \\
50 \cdot 4 \\
49 \cdot 4 \\
58 \cdot 9 \\
68 \cdot 6 \\
55 \cdot 2 \\
64 \\
67 \cdot 1 \\
64 \cdot 7 \\
58 \\
39 \\
47 \\
55 \\
41 \\
67 \cdot 7 \\
60 \\
66 \cdot 8 \\
71 \cdot 3 \\
68 \cdot 1 \\
57 \cdot 2 \\
71 \cdot 5 \\
62 \cdot 5 \\
54 \cdot 3 \\
50 \cdot 5 \\
68 \cdot 3 \\
57 \cdot 6 \\
46 \cdot 5 \\
72 \cdot 9 \\
77 \cdot 1 \\
62 \cdot 9 \\
76 \\
70 \\
71 \cdot 1 \\
60 \cdot 8 \\
60\end{array}$ \\
\hline
\end{tabular}

$F=$ female, $M=$ male, $W=$ white, $B=$ black, $S P B=$ spindle $B$ pathology, Mixed=mixed pathology, $A=$ alive, $D=$ dead.

with someone with a diploid tumour was $3.52 / 1(p<0.0001)$. Figure 4 demonstrates the univariate Kaplan-Meier survival functions for these groups. Using the log rank test, the survival of patients with aneuploid tumours was significantly worse than those with diploid tumours (log rank statistic 19.43, p<0.00001). Using the univariate data, the positive predictive value of death given an aneuploid tumour was $100 \%(10 / 10)$ and the negative predictive value given a diploid tumour was $77 \%$ (27/35) (Table 2). In order to demonstrate a biological gradient, we used linear regression and transformed linear regression models. We could not demonstrate a statistically significant worsening of survival with increasing DI among those patients with aneuploid tumours.

DNA INDEX AND PATHOLOGICAL TYPE

A statistically significant relation between DNA index and pathological type could not be found. The relative odds of having mixed pathology given that the tumour was aneuploid as against diploid was 1.17 with a $95 \%$ confidence interval between 0.47 and 1.87 .

S PHASE FRACTION AND SURVIVAL

The mean SPF of patients alive at 5 years was $2 \cdot 77 \%$ compared with $4.91 \%$ for those who died within 5 years. Using Cox's proportional hazards model, this difference was found to be significant. Specifically, the relative risk of death for each unit increase in SPF is 1.18 (variable estimate $0.165, \quad \mathrm{SE}=0.0741$, $p=0.026)$. Stated another way, for every unit increase in SPF the risk of death increased by $17 \%$.

$S$ PHASE FRACTION AND PATHOLOGICAL TYPE The mean SPF of mixed cell tumours was $5 \cdot 77 \%$ compared with $1.91 \%$ for spindle cell tumours. Using stepwise multiple logistic regression this difference was found to be statistically significant: for every unit increase in the SPF, the relative odds for having mixed pathology is 2.25 (variable estimate $=0.7997$, $\mathrm{SE}=0.2439, \mathrm{p}=0.001)$. Using the univariate data, it can be seen that $89 \%(17 / 19)$ of the tumours with an SPF greater than $4 \%$ were mixed cell tumours whereas $88 \%(23 / 26)$ of tumours with an SPF less than $4 \%$ were spindle B tumours (Table 2).

MULTIVARIATE PREDICTORS OF SURVIVAL

Using the Cox proportional hazards model, the following variables were found to be independent predictors of death within 5 years: aneuploidy, SPF greater than $4 \%$, tumours greater than $10 \mathrm{~mm}$ in diameter, extension to the ciliary body, and mixed tumours. Age, sex, race, and other ocular or systemic diseases were not significant predictors in the model.

\section{Discussion}

This study demonstrated that both ploidy and SPF were independent predictors of mortality in uveal malignant melanoma. Although among aneuploid tumours, we could not find a linear relation between increasing DNA index and shorter survival time. Hypotheses that have been proposed to explain worsening prognosis among patients with aneuploid tumours include abnormal cellular control mechanisms or a genetically unstable population of cells. ${ }^{9}$ The SPF represents the percentage of cells in the DNA synthesis phase of the cell cycle. A higher SPF among poorer prognosis

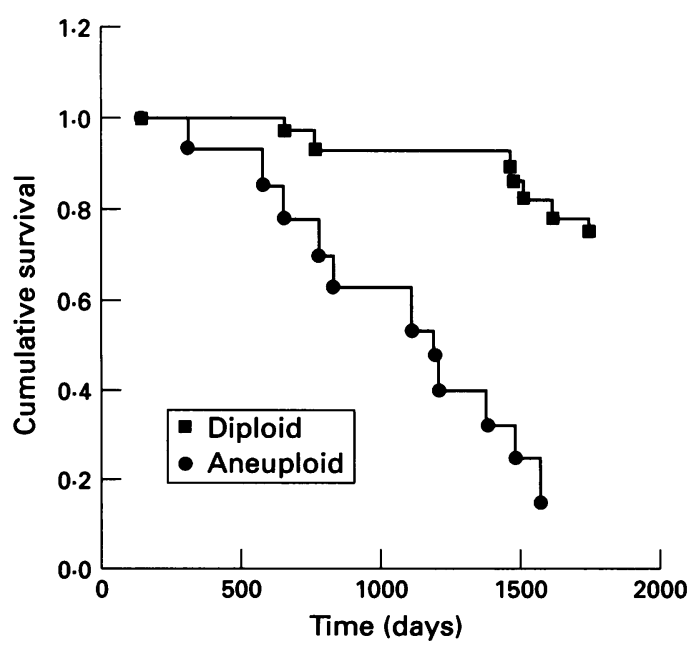

Figure 4 Kaplan-Meier curves depicting cumulative survival probability as a function of ploidy. 
Table 2 Cytometric indices, pathology, and 5 year survival

\begin{tabular}{|c|c|c|c|c|}
\hline Patient & Pathology & $\begin{array}{l}5 \text { Year } \\
\text { status }\end{array}$ & Ploidy & $S P F(\%)$ \\
\hline 1 & SP B & A & Diploid & 1.9 \\
\hline 2 & Mixed & A & Diploid & $4 \cdot 2$ \\
\hline 3 & SP B & $\mathrm{A}$ & Diploid & $3 \cdot \overline{2}$ \\
\hline 4 & Mixed & A & Diploid & $4 \cdot 1$ \\
\hline 5 & SP B & A & Diploid & $1 \cdot 2$ \\
\hline 6 & Mixed & A & Diploid & $4 \cdot 2$ \\
\hline 7 & SP B & $\mathrm{A}$ & Diploid & $2 \cdot 8$ \\
\hline 8 & SP B & A & Diploid & $1 \cdot 3$ \\
\hline 9 & Mixed & D & Aneuploid & $7 \cdot 1$ \\
\hline 10 & SP B & A & Diploid & $1 \cdot 8$ \\
\hline 11 & Mixed & A & Diploid & $2 \cdot 9$ \\
\hline 12 & Mixed & A & Diploid & $1 \cdot 2$ \\
\hline 13 & Mixed & A & Diploid & $4 \cdot 1$ \\
\hline 14 & SP B & A & Diploid & $1 \cdot 2$ \\
\hline 15 & Mixed & $\mathrm{D}$ & Aneuploid & $1 \cdot 8$ \\
\hline 16 & Mixed & A & Diploid & 5 \\
\hline 17 & Mixed & D & Diploid & $6 \cdot 1$ \\
\hline 18 & SP B & $\bar{A}$ & Diploid & 0.5 \\
\hline 19 & SP B & A & Diploid & $2 \cdot 2$ \\
\hline 20 & SP B & D & Diploid & 3 \\
\hline 21 & SP B & D & Aneuploid & $1 \cdot 7$ \\
\hline 22 & Mixed & D & Aneuploid & $4 \cdot 1$ \\
\hline 23 & SP B & D & Diploid & $1 \cdot 3$ \\
\hline 24 & SP B & $\overrightarrow{\mathrm{A}}$ & Diploid & 2 \\
\hline 25 & Mixed & D & Diploid & $6 \cdot 5$ \\
\hline 26 & Mixed & D & Diploid & 10 \\
\hline 27 & Mixed & D & Aneuploid & $4 \cdot 4$ \\
\hline 28 & Mixed & D & Diploid & $9 \cdot 8$ \\
\hline 29 & SP B & $\vec{A}$ & Diploid & $3 \cdot 4$ \\
\hline 30 & Mixed & D & Aneuploid & 8.5 \\
\hline 31 & Mixed & A & Diploid & $7 \cdot 9$ \\
\hline 32 & SP B & D & Aneuploid & $1 \cdot 3$ \\
\hline 33 & SP B & $\vec{A}$ & Diploid & $4 \cdot 1$ \\
\hline 34 & SP B & A & Diploid & 1 \\
\hline 35 & SP B & D & Aneuploid & 0.5 \\
\hline 36 & SP B & $\bar{A}$ & Diploid & $4 \cdot 4$ \\
\hline 37 & SP B & A & Diploid & 1 \\
\hline $38^{\circ}$ & SP B & A & Diploid & $1 \cdot 3$ \\
\hline 39 & Mixed & D & Diploid & $7 \cdot 5$ \\
\hline 40 & Mixed & $\bar{A}$ & Diploid & $6 \cdot 1$ \\
\hline 41 & Mixed & D & Diploid & $9 \cdot 8$ \\
\hline 42 & SP B & A & Diploid & 0.9 \\
\hline 43 & SP B & D & Aneuploid & $2 \cdot 2$ \\
\hline 44 & SP B & D & Aneuploid & $2 \cdot 7$ \\
\hline 45 & SP B & $\vec{A}$ & Diploid & 0.8 \\
\hline
\end{tabular}

SP $B=$ spindle $B$ pathology; $A=$ alive; $D=$ dead; $S P F=S$ phase fraction.

melanomas may reflect a greater biological propensity for these cells to divide (and metastasise). The SPF also correlated with histopathological subtype but the DI did not.

Flow cytometry and image analysis have been used to predict survival in both dermatological and uveal malignant melanomas with mixed results. In the ophthalmic literature, Char and associates ${ }^{915}$ have reported that both DNA and RNA ploidy correlate with duration of survival but Shapiro ${ }^{16}$ or McLean ${ }^{11}$ could find no such association. Fuchs ${ }^{17}$ attempted to study the correlation between pathological type and ploidy and could find no relation.

In the dermatological literature, the conflict is even more apparent with respect to malignant melanoma of the skin. The usefulness of DNA studies has been reflected in several reports. These include the ability to differentiate prognosis and biological behaviour among small $(<6 \mathrm{~mm})$ melanomas, ${ }^{18}$ as well as demonstrating differences among malignant melanomas and different types of benign naevi. ${ }^{1920}$ Some authors have even been able to correlate ploidy with Clarke's thickness staging. ${ }^{21}$ Others have shown that the SPF of a tumour may be able to differentiate regional from distant metastasis. ${ }^{22}$

Other authors have reported less utility with DNA studies. Waas ${ }^{8}$ found a poor correlation between aneuploidy and metastatic lesions. Lindholm ${ }^{23}$ was not able to use DNA studies to differentiate different naevi from melanomas and Slater ${ }^{24}$ could not differentiate dysplastic from intradermal naevi using these techniques. Moreover, Rode ${ }^{25}$ could not differentiate primary melanoma from metastatic lesions with cytometric studies.

The conflicting reports of the usefulness of flow cytometry have been seen in other tumours as well. For example, an adverse relation has been documented between aneuploidy and survival in human breast and colorectal carcinomas $^{26-31}$ but other authors have failed to reproduce this relation. . $^{32-37}$

Some of the reasons for this discrepancy have been put forward in a review by Wersto et al. $^{38}$ In a review of 225 studies using cytometry for human tumour prognosis, they found no less than 55 different criteria used for quantifying diploid and aneuploid tumours. Other potential confounding variables between studies include the use of fresh versus paraffin fixed tissue, choice of internal versus external controls, the DNA fluorochrome used, different sample buffers, method of calculation of the coefficient of variation, and interpretation of histogram peaks and shoulders. For all these reasons, adherence to the recommendations of the Society of Analytical Cytometry Subcommittee, SAC XIV, March 1990 was recommended and was followed in our study.

Our results have revealed the potential usefulness of DNA studies in the prognosis of uveal melanoma. However, we must review our results with caution. While both DI and SPF were significantly correlated with death in our multivariate model, we could not demonstrate a biological gradient between DNA index and survival time. Moreover, the negative predictive value of a diploid tumour was only $77 \%$ indicating some of these tumours were more biologically aggressive than revealed by our ploidy studies. The SPF did demonstrate a biological gradient but was not as strong a predictor of survival as ploidy in the multivariate model. The ultimate role of ploidy and SPF in uveal melanoma prognosis will require a series of independent standardised prospective studies on fresh tissue.

Presented in part, at the Association for Research in Vision and Ophthalmology annual meeting in Sarasota, Florida, USA, May 1993.

1 Shields J, Shields C. Intraocular tumors: a text and atlas. New York: WB Saunders, 1992: 117-36, 171-206.

2 Keefe KS, McLean IW, George DP, Davidson JK, Gamel W, Burnier MN. Prognostic value of closed vascular loops in uveal melanoma. ARVO Poster 1993: 1298.

3 Steen $\mathrm{H}$. Characteristics of flow cytometers. In: Melamed MR, Lindmo T, Mendelsohn ML, eds. Flow cytometry and sorting. 2nd ed. New York: John Wiley, 1991: and $1-65$.

4 Rowley JD. Chromosomes in leukemia and lymphoma. Semin Haematol 1978; 15: 301-19.

5 Friedlander ML, Hedley DW, Taylor IW. Clinical and biologic significance of aneuploidy in human tumours. $\mathcal{f}$ Clin Pathol 1984; 37: 961-74.

6 Haag DW, Coerttler K, Tschahargare C. The proliferation index of human breast cancer as obtained by flow cytometry. Pathol Res Prac 1984; 178: 315-22.

7 Williams NN, Dalt JM. Flow cytometry and prognostic implications in patients with solid tumors. Surg Gynecol Obstet 1990; 171: 257-65.

8 Waas J, Zbroja RA, Young GAR, Vincent PC, Joyce RM, Croaker G. Malignant melanoma: analysis by DNA flow cytometry. Pathology 1985; 17: 475-80.

9 Meecham WJ, Char DH. DNA content abnormalities and prognosis in uveal melanoma. Arch Ophthalmol 1986; 104: 1626-9. 
10 Rennie IG, Rees RC, Parsons MA, Lawry J, Cottam D. Estimation of DNA content in uveal melanomas by flow cytometry. Eye 1989; 3: 611-7.

11 McLean IW, Gamel JW. Prediction of metastasis of uveal melanoma: comparison of morphometric determination of nucleolar size and spectrophotometric determination of DNA. Invest Ophthalmol Vis Sci 1988; 29: 507-11.

12 Otsuka F, Shima A, Tshibashi Y. Porokeratosis as a premalignant condition of the skin. Cancer 1989; 63: 891-6.

13 Barlogie B, Dravinko B, Schumann J. Cellular DNA content as a marker of neoplasia in man. Am $\mathcal{F}$ Med 1980; 69: 195-203.

14 Costa A, Silvestrini R, Gringnolio E, Clemente C, Attili A, Testori A. Cell kinetics as a prognostic tool in patients with metastatic malignant melanoma of the skin. Cancer 1987; 60: 2797-800.

15 Chen TC, Char DH, Waldman F, Juster RP. Flow cytometry measurement of nuclear RNA content in uvea melanoma. Ophthalmic Res 1990; 22: 187-93.

16 Shapiro BE, Felberg NT, Donoso LA, Augsburger AJ, Shields JA, Gamel J. Flow cytometry of uveal melanomas. Cancer Biochem Biophys 1986; 8: 235-8.

17 Fuchs M, Wohlrab W, Klapperstuck T, Fuchs U. DNA flow cytometry of malignant melanoma of the choroid. Ophthalmologie 1993; 90: 496-500.

18 Kamino $H$, Kiryu H, Ratech $H$. Small malignant melanomas: Clinicopathologic correlation and DNA ploidy analysis. F Am Acad Dermatol 1990; 22: 1032-8.

19 Chi HI, Ishibashi Y, Shima A, Mihara I, Otsuka F. Use of DAPI cytofluorometric analysis of cellular DNA content to differentiate spitz nevus from malignant melanoma. f Invest Dermatol 1990; 95: 154-7.

20 Von Roenn JH, Kheir SM, Wolter JM, Coon JS Significance of DNA abnormalities in primary malignant melanoma and nevi, a retrospective flow cytometric study. Cancer Res 1986; 46: 3192-5.

21 Karlsson M, Boeryd B, Carstensen J, Kagedal B, Bratel AT, Wingren S. DNA ploidy and S-phase in primary malignant melanoma as prognostic factors for stage III disease. Br f Cancer 1993; 67: 134-8.

22 Muhonen T, Pyrhonen S, Laasonen A, Asko-Seljavaara S, Franssila K. DNA ploidy pattern and S-phase characteristics of metastatic melanoma. Virchows Arch B Cell Pathol 1991; 60: 253-7.

23 Lindholm C, Hofer PA, Jonsson H, Tribukait B. Flow DNA cytometric findings of paraffin embedded primary cutaneous melanomas related to prognosis. Virchows Arch cutaneous mell Pathol 1989; 58: 147-51.

24 Slater SD, Cook MG, Fisher C, Wright NA, Foster CS. A comparative study of proliferation indices and ploidy in dysplastic naevi and malignant melanomas using flow cytometry. Histopathology 1991; 19: 337-44.
25 Rode J, Williams RA, Chariton IG, Dhillon AP, Moss E. Nuclear DNA profiles in primary melanomas and thei metastases. Cancer 1991; 67: 2333-6.

26 Coulson PB, Thornthwaite JT, Woolley TW, Sugarbake EV, Seckinger D. Prognostic indicators including DNA histogram type, receptor content, and staging related to human breast cancer patient survival. Cancer Res 1984; 44: 4187-96.

27 Cornelisse CJ, van de Velde CJH, Caspers RJC, Moolenaar AJ, Hermans J. DNA ploidy and survival in breast cancer AJ, Hermans J. DNA ploidy and surviv

28 Emdin SO, Stenling R, Roos G. Prognostic value of DNA content in colorectal carcinomas. A flow cytometric study with some methodologic aspects. Cancer 1987; 60: 1282-7.

29 Armitage NC, Robins RA, Evans DF, Turner DR, Baldwi RW, Hardcastle JD. The influence of tumour cell DNA abnormalities on survival in colorectal cancer. $\mathrm{Br} \mathcal{F}$ Sur 1985; 72: 828-30.

30 Wolley RC, Schreiber K, Koss LG, Karas M, Sherman A. DNA distribution in human colon carcinomas and its relationship to clinical behaviour. 7 Natl Cancer Inst 1982; 69: 15-22.

31 Armitage NC, Ballantyne KC, Evans DF, Clarke $P$ Sheffield J, Hardcastle JD. The influence of tumour cell DNA content on survival in colorectal
analysis. $B r f$ Cancer $1990 ; 62$ : 852-6.

32 Melamed MR, Enker WE, Banner P, Janov AJ, Kessler G, Darzynkiewicz Z. Flow cytometry of colorectal carcinoma with three year follow-up. Dis Colon Rectum 1986; 29: 184-6.

33 Bauer KD, Lincoln ST, Vera-Roman JM, Wallemark CB, Chmiel JS, Madwiski ML, et al. Prognostic implications of proliferative activity and DNA aneuploidy in colonic proliferative activity and DNA aneuploidy in

34 Dowle CS, Owainati A, Robins A, Burns K, Ellis IO, Elston $\mathrm{CW}$, et al. Prognostic significance of the DNA content of human breast cancer. Br ₹ Surg 1987; 74: 133-6.

35 Jass JR, Mukawa K, Goh HS, Love SB, Capellaro D. Clinical importance of DNA content in rectal cancer measured by flow cytometry. F Clin Pathol 1989; 42: 254-9.

36 Uyterlinde AM, Schipper NW, Baak JPA, Peterse H, Matze E. Limited prognostic value of cellular DNA content to classical and morphometrical parameters in invasive ductal breast carcinoma. Am 7 Clin Pathol 1988; 89: 301-7.

37 Frankfurt OS, Arbuck SG, Chin JL, Grecow R, Pavelic ZP Slocum HK. Prognostic applications of DNA flow cytometry for human solid tumors. Ann NY Acad Sci 1986; 468: $276-90$.

38 Wersto RP, Liblit RA, Koss LG. Flow cytometric DNA analysis of human solid tumors: a review of the interpretation of DNA histograms. Human Pathol 1991; 22 1085-98. 